\title{
Celiac Disease and Pediatric Type 1 Diabetes: Diagnostic and Treatment Dilemmas
}

\author{
Shama Sud, ${ }^{1}$ Margaret Marcon, ${ }^{2}$ Esther Assor, ${ }^{1}$ Mark R. Palmert, ${ }^{1}$ Denis Daneman, ${ }^{1}$ \\ and Farid H. Mahmud ${ }^{1}$ \\ ${ }^{1}$ Division of Endocrinology, Department of Pediatrics, The Hospital for Sick Children, University of Toronto, Toronto, \\ ON, Canada M5G 1 X8 \\ ${ }^{2}$ Division of Gastroenterology, Department of Pediatrics, The Hospital for Sick Children, University of Toronto, Toronto, \\ ON, Canada M5G 1 X8 \\ Correspondence should be addressed to Farid H. Mahmud, farid.mahmud@sickkids.ca
}

Received 22 January 2010; Accepted 1 April 2010

Academic Editor: Paul L. Hofman

Copyright () 2010 Shama Sud et al. This is an open access article distributed under the Creative Commons Attribution License, which permits unrestricted use, distribution, and reproduction in any medium, provided the original work is properly cited.

Despite the advent of sensitive and specific serologic testing, routine screening for celiac disease (CD) in diabetic populations may not be universal practice, and many clinicians struggle to find the optimal approach to managing CD in pediatric Type 1 diabetes (T1D) patients. While some clinicians advocate screening for CD in all patients with T1D, others are unsure whether this is warranted. The diagnosis of patients who present with symptomatic CD, including malabsorption and obvious pathology upon biopsy, remains straightforward, with improvements noted on a gluten-free diet. Many patients identified by screening, however, tend to be asymptomatic. Evidence is inconclusive as to whether the benefits of screening and potentially treating asymptomatic individuals outweigh the harms of managing a population already burdened with a serious illness. This review focuses on current knowledge of CD in children and youth with T1D, highlighting important elements of the disease's pathophysiology, epidemiology, clinical presentation, and diagnostic challenges.

\section{Genetic and Clinical Considerations}

Both Type 1 Diabetes (T1D) and celiac disease (CD) result from a complex interplay between genetic susceptibility and environmental exposure. $\mathrm{CD}$ is an autoimmune enteropathy characterized by immune-mediated damage to the small intestinal mucosa triggered by ingestion of gluten, a protein complex found in wheat, rye, and barley $[1,2]$. CD and T1D have common autoimmune origins. Both are associated with the major histocompatibility complex class II antigen DQ2 encoded by the alleles, DQA1*501 and DQB1*201, thus providing a common genetic basis for disease expression $[3,4]$. Recent work has also revealed 7 shared non-HLA loci associated with CD and T1D including RGS1 on chromosome 1q31, IL18RAP on chromosome 2q12, TAGAP on chromosome 6q25, PTPN2 on chromosome 18p11, CTLA4 on chromosome 2q33, SH2B3 on chromosome 12q24, and a 32-bp insertion-deletion variant on chromosome 3p21 [3]. This shared genetic basis is strongly suggestive of a common etiology for both conditions. An increasing body of evidence derived from animal models of T1D as well as human studies [5] suggests that T1D and CD share many causative genetic and environmental factors and highlights the emerging role of dietary antigens in T1D development. This "intestinediabetes" link supposes that consumption of gluten, alone or acting synergistically with local microbial factors, results in altered gut permeability and mucosal immunity which may predispose the development of T1D [6]. Further insights into our understanding of T1D and other autoimmune conditions will likely be forthcoming through this line of research examining the impact of environmental triggers, altered immune reactivity, and abnormal intestinal permeability.

\section{Epidemiology}

Most estimates put the prevalence of $\mathrm{CD}$ at close to $1 \%$ of the general population [7-10], and recent evidence suggests that serologic prevalence rates have increased fourfold in the past 
TAble 1: Prevalence of Biopsy-Proven CD in T1D in Pediatric Populations Around the World.

\begin{tabular}{|c|c|c|c|c|c|}
\hline Geographic Location & Author & $N$ & Age (years) & Prevalence CD + DM (\%) & Study Design \\
\hline \multicolumn{6}{|l|}{ Europe } \\
\hline Finland 1996 [14] & Saukkonen et al. & 776 & $2-21$ & 2.4 & Cohort \\
\hline Spain 1998 [15] & Roldan et al. & 177 & $15.4 \pm 5.4$ & 3.9 & Cohort \\
\hline Austria 2003 [16] & Crone et al. & 157 & 14.8 & 5.1 & Prospective Cohort \\
\hline Denmark 2006 [17] & Hansen et al. & 106 & 10.8 (median) & 10.4 & Cross-sectional \\
\hline United Kingdom 2007 [18] & Goh and Banerjee & 113 & 12.1 & 4.42 & Cross-sectional \\
\hline Sweden 2008 [19] & Larsson et al. & 300 & 9.2 & 9.67 & Prospective cohort \\
\hline Italy 2008 [20] & Salardi et al. & 331 & $8.1 \pm 4.3$ & 6.65 & Retro/Prospective \\
\hline Greece 2009 [21] & Karavanaki et al. & 144 & $12.3 \pm 4.6$ & 3.47 & Cross-sectional \\
\hline \multicolumn{6}{|l|}{ North America } \\
\hline United States 2001 [22] & Aktay et al. & 218 & $4-21$ & 4.6 & Cross-sectional \\
\hline Canada 2001 [23] & Gillett et al. & 233 & children & 7.7 & Cross-sectional \\
\hline \multicolumn{6}{|l|}{ South America } \\
\hline Brazil 2005 [24] & Baptista et al. & 104 & $10.5 \pm 4.3$ & 4.8 & Cross-sectional \\
\hline \multicolumn{6}{|l|}{ Africa } \\
\hline Algeria 1996 [25] & Boudraa et al. & 116 & $1-19.5$ & 16.4 & Cohort \\
\hline Libya 2003 [26] & Ashabani et al. & 234 & $12.8 \pm 5.4$ & 10.3 & Cross-sectional \\
\hline Egypt 2005 [27] & Salah et al. & 200 & 11.2 & 4.0 & Cross-sectional \\
\hline Tunisia 2007 [28] & Mankai et al. & 205 & 11 (median) & 5.3 & Prospective cohort \\
\hline \multicolumn{6}{|l|}{ Australia } \\
\hline Australia 2000 [29] & Smith et al. & 218 & $9.9 \pm 3.8$ & 5.7 & Cross-sectional \\
\hline \multicolumn{6}{|l|}{ Middle East } \\
\hline Saudi Arabia 2003 [30] & Al-Ashwal et al. & 123 & young patients & 4.9 & Cross-sectional \\
\hline Iran 2009 [31] & Fallahi et al. & 96 & 12 (median) & 6.2 & Cross-sectional \\
\hline
\end{tabular}

50 years [11]. CD is also a global health condition that affects both developing and developed nations (Table 1). Clinicians should remain vigilant as CD is increasingly observed in nonCaucasian groups, particularly in those of North African and North Indian (Punjabi) ancestry, where incidence rates have been reported as 8 times greater than the general population $[12,13]$.

The prevalence of CD in T1D has been reported to be 57 times greater than the general population [22, 23, 32-34] with increased prevalence rates among most ethnic groups [14-31, 35]. Although sampling methods and diagnostic criteria differ among studies, rates of biopsy-proven CD in pediatric T1D range from as low as $2.4 \%$ in Finland [14] to $16.4 \%$ in Algeria [25] (Table 1).

\section{CD Presentation}

The classic presentation of CD describes symptoms related to gastrointestinal malabsorption and includes malnutrition, failure to thrive, diarrhea, anorexia, constipation, vomiting, abdominal distension, and pain. This predominance of gastrointestinal symptoms is most common in children younger than three years of age [36]. Nongastrointestinal or atypical symptoms of CD include short stature, pubertal delay, fatigue, vitamin deficiencies, and iron deficiency anemia and are more commonly observed in older children [37].
The classical presentation of CD can occur in T1D patients, but many patients with $\mathrm{CD}$ and T1D are either asymptomatic (silent CD) or present with only mild symptoms $[34,38]$. In a recent study from a North American CD clinic, $71.4 \%$ of children with diabetes reported no gastrointestinal symptoms at the time of a positive screen [36]. In reality, however, the presence and timing of "symptoms" in screened T1D patients is likely more complex. A UK study evaluated children with CD and T1D and included all retrospective data on symptoms from multiple time points obtained from notes and symptom questionnaires administered at diabetes and celiac clinics. The study reported that $13 / 17(76.4 \%)$ of patients had at least 1 gastrointestinal symptom. A questionnaire evaluating a longitudinal assessment of symptoms showed that T1D patients reported more gastrointestinal symptoms over the course of the diagnostic work-up. Initially, $86 \%$ of patients described no symptoms, but this proportion dropped to $22 \%$ at the time of intestinal biopsy [39]. While this may represent bias as to the impact of screening and counseling, it emphasizes the complex clinical spectrum of CD. For example, children may be less likely to show overt growth failure but can have weight and height measures at a lower growth percentile and complain of nonspecific symptoms, including anorexia and lassitude [40]. Some patients are overweight or obese at diagnosis; $11.2 \%$ of children with CD had a BMI greater than the 90th percentile in a recent US 
study [34]. In many high-risk populations, including T1D, $\mathrm{CD}$ can present with multiple subtle, clinical features for which clinicians must be vigilant.

\section{Screening and Diagnosis}

The introduction of serologic testing has facilitated screening at-risk populations for $\mathrm{CD}$, including conditions such as T1D as well as Down and Turner syndromes [7, 41]. Before its use, the only tool available for $\mathrm{CD}$ diagnosis was small bowel biopsy [42]. Serologic testing has also led to a rise in the rates of diagnosis of $\mathrm{CD}[43,44]$ and altered the clinical pattern of $\mathrm{CD}$ presentation. Recent Canadian data show a threefold increase in incidence rates (2 per 100,000 in 1996 to 7.3 cases per 100,000 in 2006) on the basis of serologic testing. Interestingly, rates of classical CD observed in younger children remained stable from 1990 to 2006, leading to an increase in the mean age at diagnosis, with the majority of newly diagnosed CD children identified as part of high-risk groups, including T1D [37].

Among the antibodies found in $\mathrm{CD}$, screening tests for endomysial (EMA) IgA and tissue transglutaminase (TTG) IgA have been reported to be the most sensitive and specific. Antigliadin antibodies have also been used in CD screening but are no longer recommended because of inferior sensitivities and specificities relative to EMA and TTG. A review of 32 studies using EMA IgA found a specificity of $90 \%$ to $100 \%$ (mean $99 \%$ ) and sensitivity of $86 \%$ to $100 \%$ (mean 95\%). The specificity of TTG IgA among 27 studies ranged between $86 \%$ and $100 \%$ (mean $95 \%$ ), and the sensitivity ranged between $61 \%$ and $100 \%$ (mean $87 \%$ ). As these studies were done in a research setting, it is important to note that the accuracy reported may be greater than that found in clinical practice. Although EMA appears to be more sensitive and specific than TTG, this is because some studies used guinea pig TTG which is less sensitive and specific than human recombinant protein TTG. A comparison of studies using human recombinant TTG IgA and EMA IgA found no significant difference [45]. The American Gastroenterology Association's medical position statement on the diagnosis and management of celiac disease recommends use of the TTG IgA test for the initial detection of CD as it is less time consuming and operator dependent than the EMA IgA test [46]. It must be emphasized that all diagnostic tests must be performed while the patient is on a glutencontaining diet. Furthermore, serologic testing for children less than 5 years of age is less reliable due to age related changes in immunogenicity. It is also unfortunate that the cost of TTG testing outside of hospital is not covered in many jurisdictions, thereby reducing the availability of $\mathrm{CD}$ screening in community-based practices.

IgA deficiency occurs more commonly in $\mathrm{CD}$ than in the general population, making the identification of certain patients with CD using serology difficult [47]. While studies looking at IgA deficiency in the general population have reported rates from 1 in 400 to 18,500 people [48-50], in the $\mathrm{CD}$ population rates have been reported as high as 1 in 39 to 57 people $[51,52]$. If a partial or absolute IgA deficiency is found, EMA IgG or TTG IgG tests are recommended as both are sensitive and specific [46].

Once patients are identified as screen positive, they should be referred to a gastrointestinal specialist for evaluation and consideration of intestinal biopsy. Biopsy remains the gold standard of diagnosis, and endoscopic evaluation with biopsies from multiple intestinal sites is preferred because $\mathrm{CD}$ can present with variable biopsy findings, and nonfocal or "patchy" histopathologic lesions have been observed from duodenal samples in over $50 \%$ of children and up to $25 \%$ of adults $[53,54]$.

\section{Current Screening Recommendations}

Consensus-based guidelines developed by the Canadian Diabetes Association (CDA), the American Diabetes Association (ADA), the International Society for Pediatric and Adolescent Diabetes (ISPAD), the North American Society for Pediatric Gastroenterology and Hepatology (NASPGHAN), and the National Institutes of Health (NIH) differ in their screening and treatment recommendations for patients with T1D (Table 2) [55-59]. The ADA recommends screening T1D patients for $C D$ and placing all children with a confirmed diagnosis of $\mathrm{CD}$ on a gluten-free diet (GFD) [58]. ISPAD suggests that while it seems sensible to put an asymptomatic child on a GFD to avoid the development of complications, limited data are available to support this. Therefore, they recommend that children with confirmed $\mathrm{CD}$ and T1D receive support from a pediatric dietician [55]. NASPGHAN recommends screening T1D patients for CD and a GFD for asymptomatic children with an associated condition such as T1D but acknowledges that there is little evidence to suggest that a GFD leads to improvements in diabetes in the short-term. Conversely, current CDA guidelines advise screening symptomatic T1D patients and emphasizes informing parents that the treatment of asymptomatic CD in T1D is controversial [57]. An NIH sponsored consensus document (2004) also recommends screening symptomatic T1D patients for CD only and treating all patients with biopsy-proven CD [59]. These disparate recommendations leave clinicians without a concrete method of patient management and speak to the absence of available literature for development of an evidence-based approach.

\section{Treatment with a Gluten-Free Diet}

Currently, the only effective treatment in use for $\mathrm{CD}$ is a GFD, although new treatments are being developed. As defined, a GFD excludes wheat, rye, and barley and should be strict, as even trace amounts of gluten may provoke intestinal inflammation [59]. However, there is no accepted definition of what constitutes a "safe" amount of dietary gluten. Uncontaminated dry-rolled oats in limited amounts are considered safe for inclusion as part of a GFD, but care must be exercised as there is a potential for contamination with gluten during processing [60].

For symptomatic patients, adherence to a GFD most often leads to resolution or improvement of symptoms 
TABLe 2: Clinical Recommendations for Screening and Treatment of CD in T1D.

\begin{tabular}{|c|c|c|c|c|c|}
\hline \multirow{2}{*}{ Organization } & \multirow{2}{*}{$\begin{array}{l}\text { Indications for } \\
\text { Screening/Investigation }\end{array}$} & \multirow{2}{*}{ Screening Test } & \multirow{2}{*}{ Frequency } & \multicolumn{2}{|c|}{ Treatment } \\
\hline & & & & Symptomatic & Asymptomatic \\
\hline $\begin{array}{l}\text { International } \\
\text { Society for } \\
\text { Pediatric and } \\
\text { Adolescent } \\
\text { Diabetes [55] } \\
\text { (Consensus Based) }\end{array}$ & $\begin{array}{l}\text { (i) Diarrhea, flatulence } \\
\text { (ii) Unexplained poor } \\
\text { growth } \\
\text { (iii) Abdominal pain } \\
\text { (iv) Dyspeptic symptoms } \\
\text { (v) Anemia } \\
\text { (vi) Recurrent aphthous } \\
\text { ulceration }\end{array}$ & $\begin{array}{l}\text { (i) IgA levels } \\
\text { (ii) EMA and TTG } \\
\text { IgA }\end{array}$ & $\begin{array}{l}\text { (i) At time of T1D } \\
\text { diagnosis and every } \\
\text { second year thereafter } \\
\text { (ii) If clinical situation } \\
\text { suggests possible CD, or if } \\
\text { the child has first-degree } \\
\text { relative with CD, more } \\
\text { frequent assessment is } \\
\text { indicated }\end{array}$ & Gluten-free diet & $\begin{array}{l}\text { Gluten-free diet } \\
\text { may be considered } \\
\text { justified with goal } \\
\text { of reducing risk of } \\
\text { complications. }\end{array}$ \\
\hline $\begin{array}{l}\text { Canadian Diabetes } \\
\text { Association [57] } \\
\text { (Evidence Grade } \\
\text { D: Consensus) }\end{array}$ & $\begin{array}{l}\text { (i) Symptoms of classic or } \\
\text { atypical CD } \\
\text { (ii) Poor linear growth } \\
\text { (iii) Fatigue } \\
\text { (iv) Recurrent GI } \\
\text { symptoms } \\
\text { (v) Poor weight gain } \\
\text { (vi) Anemia, } \\
\text { (vii) Unexplained frequent } \\
\text { hypoglycemia/poor } \\
\text { metabolic control }\end{array}$ & $\begin{array}{l}\text { (i) TTG } \\
\text { (ii) IgA levels }\end{array}$ & $\begin{array}{l}\text { (i) Based on clinical } \\
\text { symptoms }\end{array}$ & Gluten-free diet & $\begin{array}{l}\text { Parents should be } \\
\text { told treatment of } \\
\text { asymptomatic CD } \\
\text { with gluten-free } \\
\text { diet in T1D is } \\
\text { controversial. }\end{array}$ \\
\hline $\begin{array}{l} \\
\text { American Diabetes } \\
\text { Association [58] } \\
\text { (Evidence Grade E: } \\
\text { Consensus) }\end{array}$ & $\begin{array}{l}\text { (i) Failure to gain weight } \\
\text { (ii) Gastroenterologic } \\
\text { symptoms } \\
\text { (iii) Growth failure } \\
\text { (iv) Weight loss } \\
\text { (v) Recent T1D diagnosis }\end{array}$ & $\begin{array}{l}\text { (i) TTG or EMA } \\
\text { (ii) IgA levels }\end{array}$ & $\begin{array}{l}\text { (i) Periodic re-screening } \\
\text { of asymptomatic } \\
\text { individuals or if } \\
\text { indications for screening } \\
\text { develop }\end{array}$ & Gluten-free diet & $\begin{array}{l}\text { All children with } \\
\text { confirmed } \\
\text { diagnosis of CD } \\
\text { should be put on a } \\
\text { gluten-free diet. }\end{array}$ \\
\hline $\begin{array}{l}\text { North American } \\
\text { Society for } \\
\text { Pediatric } \\
\text { Gastroenterology, } \\
\text { Hepatology and } \\
\text { Nutrition [56] } \\
\text { (Consensus Based) }\end{array}$ & $\begin{array}{l}\text { (i) Non-GI symptoms of } \\
\text { CD (osteoporosis, short } \\
\text { stature, dermatitis } \\
\text { herpetiformis, delayed } \\
\text { puberty, iron-deficient } \\
\text { anemia) } \\
\text { (ii) Other (autoimmune } \\
\text { thyroiditis, T1D, Williams } \\
\text { syndrome, Down } \\
\text { syndrome, Turner } \\
\text { syndrome) }\end{array}$ & (i) TTG IgA & $\begin{array}{l}\text { (i) Asymptomatic } \\
\text { individuals who belong to } \\
\text { high risk groups with } \\
\text { negative serological tests } \\
\text { should be considered for } \\
\text { repeat testing at intervals }\end{array}$ & Gluten-free diet & $\begin{array}{l}\text { Gluten-free diet } \\
\text { recommended for } \\
\text { asymptomatic } \\
\text { children with an } \\
\text { associated } \\
\text { condition such as } \\
\text { T1D. }\end{array}$ \\
\hline
\end{tabular}

$[17,61]$. Conversely, nonadherence to a GFD in patients with symptomatic CD is the primary reason for a lack of improvement following CD diagnosis [62-64]. A single longterm follow-up study from France retrospectively examined 61 symptomatic patients diagnosed in childhood with biopsy positive CD who subsequently discontinued the GFD [65]. After a latency period of 10 years on a normal, gluten containing diet, $47 \%$ reported mild clinical symptoms, and $80 \%$ had evidence of CD on repeat intestinal biopsy.

It remains unclear whether asymptomatic patients experience long- and/or short-term health related benefits from following a GFD $[38,66]$. To our knowledge, no clinical studies have followed the natural progression of $\mathrm{CD}$ in patients with asymptomatic $C D$, and any beneficial effects of strict compliance with a GFD in asymptomatic patients with $\mathrm{CD}$ and T1D remain unknown.

\section{Adherence to a GFD}

Adherence to a GFD varies among patients with $\mathrm{CD}$, with rates ranging from 23.8 to $81 \%$ (Table 3) [38, 61, 67-75]. In children with $\mathrm{CD}$ and $\mathrm{T} 1 \mathrm{D}$, less than $30 \%$ were strictly compliant with a GFD $[17,67,71]$. The majority of patients were, at minimum, ingesting trace amounts of gluten. This variability in compliance stems from differences in criteria used to define compliance, the methods used to measure compliance, whether subjects were identified by symptoms or screening, and age at diagnosis. Lower compliance has been found in adolescents diagnosed via mass serological screening than in patients matched for age who were diagnosed with typical symptoms during childhood $[61,76]$. Patients diagnosed with CD at a very young age have been found to have the highest rates of compliance. In Sweden, 
Table 3: Levels of GFD Compliance in Pediatric Populations.

\begin{tabular}{|c|c|c|c|c|c|c|}
\hline Author & Country & $n$ & Age & $\begin{array}{l}\text { Length of } \\
\text { Follow-up }\end{array}$ & Mode of Follow-up & GFD Compliance (\%) \\
\hline \multirow[t]{3}{*}{ Westman et al. 1999 [67] } & Australia & $20 \mathrm{CD}+\mathrm{DM}$ & $6.9-17.4$ & $\mathrm{~N} / \mathrm{A}$ & 7 day food record & 30 (strict) \\
\hline & & & & & & 30 (trace gluten diet) \\
\hline & & & & & & 40 (non-compliant) \\
\hline \multirow[t]{2}{*}{ Mariani et al. 1998 [68] } & Italy & $47 \mathrm{CD}$ & $15.2 \pm 2.3$ & N/A & Diary & 53.2 (compliant) \\
\hline & & & & & EMA* $^{*}$ & 46.8 (non-compliant) \\
\hline \multirow[t]{3}{*}{ Greco et al. 1997 [69] } & Italy & $306 \mathrm{CD}$ & 12 & Unclear & Diary & 73 (strict) \\
\hline & & & & & GI consultant & 15 (occasional gluten) \\
\hline & & & & & Repeat Biopsy & $\begin{array}{l}12 \text { (frequent } \\
\text { transgressions/full } \\
\text { gluten-containing diet) }\end{array}$ \\
\hline \multirow[t]{2}{*}{ van Koppen et al. 2009 [70] } & Netherlands & $32 \mathrm{CD}$ & $12-14$ & 10 years & Interview & 81 (compliant) \\
\hline & & & & & & 19 (non-compliant) \\
\hline \multirow[t]{4}{*}{ Saadah et al. 2004 [71] } & Australia & $21 \mathrm{CD}+\mathrm{DM}$ & 7.5 & 1 year & $\begin{array}{c}\text { Structured telephone } \\
\text { questionnaire }\end{array}$ & 25.0 (Excellent) \\
\hline & & & & & & 60.0 (Good) \\
\hline & & & & & & 5.0 (Fair) \\
\hline & & & & & & 10 (Poor) \\
\hline \multirow[t]{3}{*}{ Wagner et al. 2008 [72] } & Austria & $283 \mathrm{CD}$ & $10-20$ & N/A & Questionnaire & 80.8 (strict) \\
\hline & & & & & & $\begin{array}{l}14.9(2-3 \\
\text { transgressions/month) }\end{array}$ \\
\hline & & & & & & $\begin{array}{l}4.3 \text { (more frequent } \\
\text { transgressions) }\end{array}$ \\
\hline \multirow[t]{3}{*}{ Hopman et al. 2006 [73] } & Netherlands & $132 \mathrm{CD}$ & $16.6 \pm 4.4$ & N/A & Questionnaire & 75 (strict) \\
\hline & & & & & & $\begin{array}{l}23 \text { (occasional } \\
\text { consumption) }\end{array}$ \\
\hline & & & & & & 2 (non-compliant) \\
\hline \multirow[t]{3}{*}{ Jadresin et al. 2008 [74] } & Croatia & $71 \mathrm{CD}$ & 12 & & Questionnaire & 53 (strict) \\
\hline & & & & & & $\begin{array}{l}26.4 \text { (small amounts of } \\
\text { gluten) }\end{array}$ \\
\hline & & & & & & 20.6 (non-compliant) \\
\hline \multirow[t]{2}{*}{ Fabiani et al. 1996 [61] } & Italy & $28 \mathrm{CD}$ & $11-14$ & $23 \pm 7$ months & Questionnaire & $52.2($ strict $)$ \\
\hline & & & & & EMA & $\begin{array}{l}47.8 \text { (occasional } \\
\text { transgression) }\end{array}$ \\
\hline \multirow[t]{2}{*}{ Rami et al. 2005 [38] } & Austria & $74 \mathrm{CD}+\mathrm{DM}$ & $6.5 \pm 4.1$ & $3.3 \pm 1.9$ years & EMA & 44.6 (compliant) \\
\hline & & & & & & 55.4 (non-compliant) \\
\hline \multirow[t]{3}{*}{ Anson et al. 1990 [75] } & Israel & $43 \mathrm{CD}$ & $<18$ & $6.9 \pm 3.3$ & Assessment of & 70 (compliant) \\
\hline & & & & & symptoms, biopsy and & 28 (non-compliant) \\
\hline & & & & & antireticulin antibodies & 2 (unclassified) \\
\hline
\end{tabular}

* EMA refers to antiendomysial antibody.

only $36 \%$ of adults diagnosed with CD over the age of 4 years were compliant, as compared to $80 \%$ diagnosed before the age of 4 [77].

It is challenging for clinicians and dieticians to assess individual patient adherence to the GFD, especially in older children and adolescents who eat outside of parental supervision. Dietary interviews may be helpful but are often nonstandardized, time intensive, and subjective. Furthermore, few physicians and dieticians are sufficiently well trained to evaluate GFD adherence. Repeat CD serologic testing (TTG IgA), with declines noted after 6 months on a GFD, may be used to follow adherence, but these tests have been shown to have variable sensitivity in evaluating gluten exposure in adult studies [78]. Reassessment with repeat endoscopy is also available to directly assess pathology, albeit an invasive, expensive and less viable option for routine pediatric cases. Despite the difficulty of assessing individual GFD adherence, some key questions posed to CD patients including the frequency of purposeful gluten ingestion and an individual patient or family's ability to follow a GFD 
TAble 4: Metabolic Control Measures Following a GFD in CD Positive Patients.

\begin{tabular}{|c|c|c|c|c|c|c|c|}
\hline \multirow{2}{*}{ Author } & \multirow[t]{2}{*}{ Study Design } & \multicolumn{2}{|r|}{$N$} & \multirow[t]{2}{*}{ Age } & \multirow{2}{*}{$\begin{array}{l}\text { Growth Improvement } \\
\text { Effect }\end{array}$} & \multirow{2}{*}{$\begin{array}{l}\text { HbA1C } \\
\text { Change }\end{array}$} & \multirow{2}{*}{$\begin{array}{l}\text { Hypoglycemic } \\
\text { Episodes }\end{array}$} \\
\hline & & DM & $\mathrm{CD}+\mathrm{DM}$ & & & & \\
\hline \multirow[t]{2}{*}{$\begin{array}{l}\text { Hansen et al. } 2006 \\
{[17]}\end{array}$} & $\begin{array}{l}\text { Cohort (2 year } \\
\text { follow-up) }\end{array}$ & 236 & 33 & $1.5-16$ & Ht NS* & NS & $\downarrow \downarrow$ \\
\hline & & & & & $\mathrm{Wt} \uparrow \uparrow$ & & \\
\hline \multirow[t]{2}{*}{$\begin{array}{l}\text { Sanchez-Albisua et } \\
\text { al. } 2005 \text { [81] }\end{array}$} & $\begin{array}{l}\text { Longitudinal (1-5 } \\
\text { years follow-up) }\end{array}$ & 263 & 9 & $12 \pm 5$ years & $\mathrm{Ht} \uparrow \uparrow * *$ & NS & $\downarrow \downarrow$ \\
\hline & & & & & Wt NS & & \\
\hline \multirow[t]{3}{*}{$\begin{array}{l}\text { Saadah et al. } 2004 \\
{[71]}\end{array}$} & $\begin{array}{l}\text { Cohort (1 year } \\
\text { follow-up) }\end{array}$ & 42 & 21 & $1.6-12.9$ & Ht NS & NS & $\mathrm{NE}$ \\
\hline & & & & & $\mathrm{Wt} \uparrow \uparrow$ & & \\
\hline & & & & & $\mathrm{BMI} \uparrow \uparrow$ & & \\
\hline \multirow[t]{2}{*}{$\begin{array}{l}\text { Rami et al.2005 } \\
{[38]}\end{array}$} & $\begin{array}{l}\text { Case-control }(3.3 \pm 1.9 \\
\text { years follow-up) }\end{array}$ & 195 & 98 & $10.0 \pm 5.4$ & Ht NS & NS & NS \\
\hline & & & & & BMI NS & & \\
\hline \multirow[t]{3}{*}{ Sun et al. 2009 [82] } & $\begin{array}{l}\text { Case-Control (2 year } \\
\text { follow-up) }\end{array}$ & 49 & 49 & $6.0 \pm 4.1$ & Ht NS & $\uparrow \uparrow$ & N/A \\
\hline & & & & & Wt NS & & \\
\hline & & & & & BMI NS & & \\
\hline
\end{tabular}

* Subgroup analysis excluding patients $>14$ at study onset found significant increase in Ht SDS.

$* *$ Data for well-complying patients.

NE: not evaluated.

NS: not significant.

outside the home are strongly predictive of GFD adherence $[79,80]$.

The benefits of adherence with a GFD in patients with T1D in regards to clinically relevant outcomes are mixed $[17,38,71,81,82]$ (Table 4). Height (SD) was reported to increase in those well-compliant with a GFD in one study [81], while other studies reported no significant improvements $[17,38,71,82]$. Improvements in weight $[17,71]$ and BMI [71] have also been reported, but this is not true for all studies [38, 81, 82]. A single pediatric study has reported a significant increase in HbA1C levels after following a GFD [82], while the remainder have reported no change $[17,38,71,81]$. A decrease in the number of hypoglycemic episodes was noted in some studies $[17,81]$ but not in another [38]. The discordant findings among studies, small numbers of patients studied, as well as lack of distinction between symptomatic and asymptomatic patients, make it difficult to comment on the real impact of adherence to a GFD in patients with T1D.

\section{Barriers to Adherence}

While a GFD is the current method of treatment for CD, few studies have examined the practicality of following it, particularly among adolescents and children with T1D. One area with limited data is the barriers to compliance with a GFD among adolescents and children. Factors reported to affect the likelihood of compliance include unavailability of gluten-free food, problems with sensory acceptance, inadequate support from family and peers, absence of symptoms following ingestion of gluten, and lack of knowledge of the health-related harms of gluten ingestion [83].

An additional barrier to adherence is the economic feasibility of living with the GFD $[84,85]$. Gluten-free food is considerably more expensive than its gluten-containing counterpart. A cost comparison found that the unit price of gluten-containing food was $\$ 0.61 \pm 0.38$ as compared with $\$ 1.71 \pm 0.93$ for gluten-free food. Gluten-free foods were on average $242 \% \pm 212$ more expensive than glutencontaining foods [85]. This increase in cost is largely related to the fact that additional starches and additives are added to gluten-free items to mimic the properties of wheat-based flours [86].

The availability of gluten-free food measured in 5 different US states was also found to be significantly less than food containing gluten [84] and has been reported as a barrier to compliance [83]. The availability of gluten-free food has not been examined in developing countries. As the number of people diagnosed with CD continues to grow, ensuring the ready availability of gluten-free food worldwide and integrating it into the general food supply will become increasingly important. In Canada, in 2008 Health Canada proposed changes to food labeling regulations; specifically, the label "gluten free" would mean that a product does not contain wheat, oats, barley, rye, or any ingredients derived from these grains [87]. While useful, this would not address cross contamination of bin foods such as rice, where the consumer would not expect to find gluten. 


\section{Wellbeing and Quality of Life}

Another important consideration is the putative effect of a GFD on wellbeing in children with T1D [88]. T1D alone has been shown to have a significant negative impact on quality of life in adolescents [89-91]. In adult diabetes patients, psychosocial issues have been found to supersede metabolic measures in predicting negative outcomes [92]. Living with a GFD may impact quality of life. Symptomatic adults with $\mathrm{CD}$ have been found to have poorer quality of life than asymptomatic patients at diagnosis; this improves only in symptomatic patients with either strict or partial adherence with a GFD after 1 year $[92,93]$. Another study found no change in quality of life in screen-detected patients following a GFD [94]. A recent study in adolescents with CD aged 10-20 years observed worse quality of life in those not compliant with the GFD, with older teens experiencing more school and social problems than healthy teen controls [72]. Overall, these data emphasize the importance of evaluating psychological well-being in pediatric $\mathrm{CD}$, particularly the asymptomatic at-risk group. This is especially relevant in the context of T1D, where patients with diabetes must manage two chronic conditions.

\section{Emerging Alternatives to the GFD}

Alternatives to the GFD are being developed, and these novel treatments may lead to viable treatment opportunities. Enzyme therapy products using combinations of endoprotease/endopepitidases may increase amount of ingested gluten that can be safely tolerated [95]. Intestinal permeability inhibitors may reduce small intestine permeability upon gluten exposure, thus decreasing inflammation [96]. Modalities to target the HLA molecule using DQ2-peptideblockers may prevent DQ2 mediated antigen presentation to $\mathrm{T}$ cells, an important event in the pathogenesis of CD [97]. These modalities are currently investigational but may allow for alternative adjunct or replacement treatment strategies for the GFD in CD-affected patients in the future.

\section{CD-Related Complications: Are They Similar in T1D-Screened Patients?}

A leading reason for screening asymptomatic individuals is to institute early treatment, thereby mitigating the risk of long-term CD-related complications, specifically osteopenia/osteoporosis, small bowel lymphoma, reproductive problems, and the overall enhanced mortality associated with CD [98].

11.1. Bone Health. In children, osteoporosis is defined as a general skeletal disorder characterized by low bone mass and a microarchitectural deterioration of bone tissue which results in increased bone fragility and increased susceptibility to fractures [99]. Osteoporosis represents the most insidious complication with greatest potential public health impact of early identification of CD in T1D patients. It is important to appreciate that during childhood bone mass development, bone mineral content increases in a linear fashion and is related to weight, height, and pubertal development. Other significant determinants of peak bone mass include adequate nutrition with respect to calcium and vitamin $\mathrm{D}$ status. These work in concert with sex steroids and growth hormone to contribute to the significant changes that occur during the pubertal time period with the eventual attainment of peak bone mass in the second decade of life [100].

$\mathrm{CD}$ has been associated with decreased bone mineral density (BMD) in adolescents and children [101-105]. Tau et al. [104] reported mean lumbar spine BMD Z-scores as measured by DXA at $-1.36 \pm 1.20$ in 24 children at diagnosis; this improved by over $1 \mathrm{SD}$ after 1 year on the GFD. A Canadian study found no differences in BMD Z-scores between children with $\mathrm{CD}(9.6 \pm 3.7$ years $)$ who presented with or without symptoms at diagnosis. However BMD Zscores were low in both groups with $16.7 \%$ of symptomatic children and $14.3 \%$ of asymptomatic children with a Z-score less than or equal to -2 SD [106]. A single long-term followup study from France retrospectively examined symptomatic patients diagnosed in childhood with biopsy positive $C D$ who subsequently discontinued the GFD [65]. After a latency period of 10 years on a normal diet, $70 \%$ had low BMD Zscores between -1 and $-2.5 \mathrm{SD}$.

The etiology behind the low BMD seen in adolescents and children with CD remains unclear. Decreased calcium intake and absorption has been reported [107]. However, some studies have reported serum calcium levels to be within the normal range at CD diagnosis [104, 108], with a small increase following a GFD [108]. Vitamin D levels $(25 \mathrm{OH}$ D) in CD patients have been shown to be comparable to controls at diagnosis, although levels increased on the GFD [104, 109]. Studies looking at parathyroid hormone have shown mixed results, with several reporting normal values $[103,104,108]$ and others reporting elevated levels of parathyroid hormone in CD patients at diagnosis [110112]. An imbalance between the cytokines osteoprotegerin and receptor activator of nuclear factor KappaB ligand (RANKL) is an alternate explanation for low BMD in CD. The regulatory role of cytokines on cells involved in bone formation and breakdown has been well documented [113116]. RANKL is expressed by osteoblasts and activates the development of osteoclasts. When the macrophage stimulating factor is present, RANKL activates its receptor RANK [117], leading to formation and activation of osteoclasts [118]. Osteoprotegerin inhibits RANKL activity by binding to it [119]. Evidence of an imbalance in the levels of RANKL and osteoprotegerin has been found in adult patients with CD $[120,121]$, suggesting that they may play a role in decreased BMD in CD.

Low BMD has also been found in persons with T1D, [122-124] and may further increase the risk of osteoporosis in adulthood $[125,126]$. Studies have reported that following a GFD improves BMD in CD [101-103, 127-129]. But few studies have examined BMD levels in adolescents and children with CD and T1D [130-132]. Results have been discordant with some studies reporting lower BMD in patients with CD and T1D [130, 132] and another finding no difference [131]. 
11.2. Lymphoma. The increased incidence of non-Hodgkin lymphoma in CD has been well established [133, 134]. Enteropathy-associated T-cell lymphoma (EATCL) specifically has been estimated to occur 50 times more in symptomatic CD than in the general population [135]. Following a strict GFD for a minimum of 5 consecutive years has been shown to protect against the development of lymphoma [135]. To our knowledge, only one retrospective study in Switzerland has reported on the incidence of EATCL in patients with $\mathrm{CD}$ and T1D. Investigators identified 10 cases of EATCL in the Swiss population. Five patients had a history of malabsorption; however, none had T1D [66]. Investigators reported that the expected risk for EATCL is $12.4 / 100000$ in patients with T1D over a 60-year period and suggested that the risk of developing EATCL alone is not high enough to warrant routine screening for $\mathrm{CD}$ in T1D [66].

11.3. Reproduction. CD has been associated with reproductive problems at different time points in adult populations. Men with CD have been found to have a greater incidence of sexual dysfunction, hypogonadism, and poor semen quality [136]. Delayed menarche, increased secondary amenorrhea, and early menopause have been documented in women newly diagnosed with CD $[137,138]$. In women following a GFD for an extended period of time, however, no difference was found from controls in terms of the timing and frequency of these events [139]. Rates of spontaneous abortions have also been reported to be significantly higher in women with untreated CD than healthy controls [137, 138]. In addition, patients with untreated CD who have successful pregnancies have been found to have more low-birth weight babies than healthy controls [140-143]. However a population-based study done in the UK found no difference in fertility rates or pregnancy outcomes between women with untreated CD and healthy controls, making it difficult to elucidate the true impact of CD on fertility in women [144]. A single study done in Italy compared the long-term reproductive outcomes of adults diagnosed with $\mathrm{CD}$ in childhood to those diagnosed with CD later in life. Researchers did not find a difference in the age at menarche, the number of pregnancies or the number of abortions between patients who remained on GFD from childhood, patients who reverted back to a gluten-containing diet after a minimum of one year (diagnosed in childhood), and patients who had never been on a GFD (newly diagnosed). However, patients diagnosed with $\mathrm{CD}$ as adults that had never followed a GFD and patients who reverted back to a gluten-containing diet had significantly lower weight babies and an increased incidence of threatened abortions than patients who had been following a strict GFD since diagnosis in childhood [145]. To our knowledge no studies have examined the impact of $\mathrm{CD}$ on reproduction in the T1D population. Although the impact of untreated CD on fertility is not completely understood at this point, the literature does suggest a shortened fertility period for women with $\mathrm{CD}$ and a greater risk of low-birth weight babies.
11.4. Long-Term Mortality Risk. There is epidemiologic evidence from Sweden, Germany, and the US which describe increased mortality rates in adult patients with undiagnosed celiac disease. A recent study evaluated TTG and EMA antibodies from blood samples fortuitously obtained from a historical cohort of US military personnel who had blood samples saved between 1948 and 1954. The assessment of subsequent survival showed a fourfold higher mortality risk (3.9, CI 2.0-7.5, $P<.001)$ for CD serology positive subjects than for CD negative subjects [11]. Larger adult German cohorts with elevated TTG IgA levels had increased ageadjusted hazard ratios or $1.86(1.01-3.41)$ for men and 3.92 (1.44-10.71) for women [146]. A Swedish study examined mortality risk in CD using small intestinal pathology and reported increased hazard ratio for death in CD of 1.39 (95\% CI 1.33-1.45) in relation to age and sex-matched controls from the general population (146). Mortality in pediatric CD (0-19 years) was also increased (HR 1.9; $1.25-2.89)$. The majority of this increased mortality risk was malignancy or cardiovascular disease related. The numbers of patients in these studies is small and cause of death is variable, but they suggest that additional, hitherto undetermined risk may be present, influencing long-term health and survival in patients with serology positive, undiagnosed CD.

\section{The Screening Dilemma}

Many patients and their caregivers are apprehensive about CD screening in the context of T1D. For patients and families, diabetes is a challenging condition requiring daily efforts to balance meals, activity, and insulin to maintain adequate metabolic control. In adult diabetic patients, the presence of complications is associated with worsened quality of life [41, 42]. The impact of an additional chronic disease, such as CD, may substantially affect the quality of life in such patients, although research has not evaluated this question directly. Clinicians are also challenged by the fact that while screening tests are safe and effective, follow-up of positive serologic screens requires access to gastroenterologic consultation with invasive testing, as biopsy confirmation of intestinal damage remains the diagnostic gold standard. Lastly, maintaining a strict GFD in addition to a diabetic diet requires additional time, effort, and expense. It is not surprising that most T1D patients struggle with strict adherence to a GFD (Table 3).

Significant gaps exist in our understanding of the natural history of undiagnosed CD in T1D patients. We do not know if the outcomes of those identified by screening are similar to those who are clinically identified nor is it clear whether earlier identification, before the onset of clinical symptoms, impacts long-term outcome. Treatment options beyond a strict GFD, particularly for asymptomatic patients, must be explored as well. This would also benefit symptomatic patients who are not entirely compliant with a GFD. We also need to determine if a minimal threshold of gluten in the diet exists and is safe. In the long term, the impact of screening and treatment as they pertain to clinically relevant outcomes such as bone mineralization, diabetes control, and wellbeing are important questions worthy of study. 


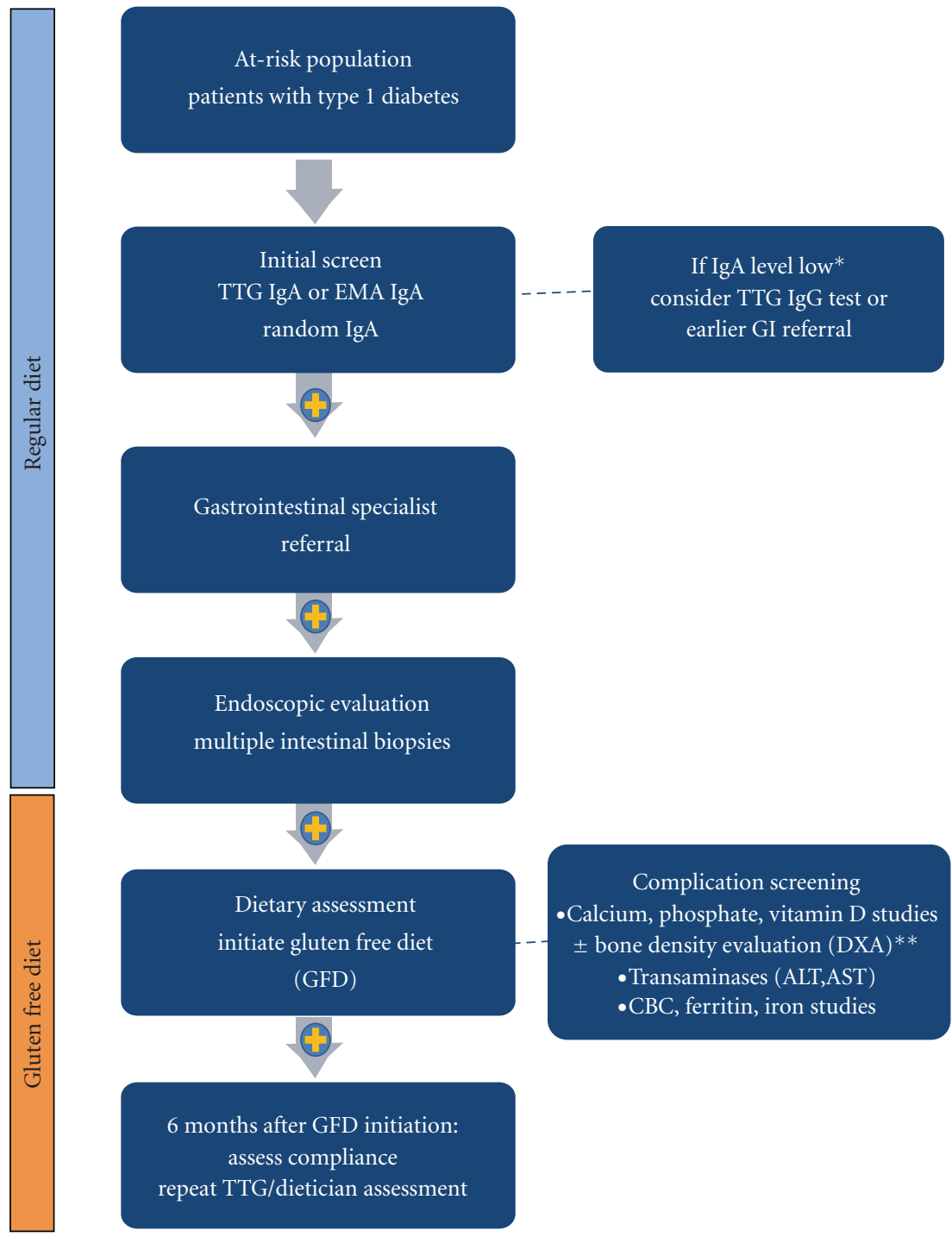

Figure 1: Proposed Screening Schema for Patients At-risk for CD. ${ }^{*}$ Low IgA levels may require additional testing of total immunoglobulins. ** DXA scans should be considered for patients at baseline especially with positive evidence of familial osteoporosis, fracture history, delayed puberty, or abnormal calcium/vitamin D studies.

Despite these concerns, the prevalence of $\mathrm{CD}$ is higher in T1D: between 5-7-fold higher than the general population [34]. Although some guidelines recommend that screening for CD should only in symptomatic T1D patients, many institutions, including ours, have embarked on screening programs as part of routine diabetic care. A proposed screening strategy with consideration of complication screening is outlined in Figure 1. In our experience it is difficult to determine which patient is symptomatic, as most busy diabetes clinics do not routinely screen for many of the myriad of CD-related symptoms. But if clinicians overlook minor GI symptoms or ascribe them to complications of longstanding diabetes, a practice of routine testing may detect these symptomatic patients. From a medical perspective, numerous advantages may exist in screening asymptomatic patients with diabetes, including the potential of improved diabetic control and avoidance of long-term manifestations of CD. Impaired bone mineralization in adolescent patients with ongoing, unrecognized intestinal inflammation is of particular concern. Recent population-based and cohort 
studies examining adults with undiagnosed, serology positive CD had significant higher mortality than controls [11, 146, 147], inferring that undiagnosed celiac disease is not a benign condition and questioning the ethics of asking or randomizing patients with CD not to pursue treatment.

The dilemma of screening for CD in T1D is complex. The classic CD presentation of a miserable, malnourished toddler is no longer typical, as patients who present are sometimes overweight and come from many ethnic groups. CD and T1D share common genetic origins and an increasing body of evidence identifies this intestinal insult as a provocative factor in the pathogenesis of T1D and other autoimmune conditions. For these reasons, it is important to emphasize to clinicians caring for pediatric patients that CD appears at a much higher rate in patients with diabetes and can present with multiple gastrointestinal and nonintestinal features. The challenge remains to follow the precept of primum non nocere: first do no harm in our approach to these patients and further evaluate the risks and benefits of screening relevant to clinically important outcomes.

\section{Abbreviations}

BMD: Bone mineral density

CD: Celiac disease

GFD: Gluten-free diet

SD: Standard deviation

T1D: Type 1 diabetes

TTG: Tissue transglutaminase

DXA: Dual-energy X-ray absorptiometry

\section{References}

[1] A. Fasano, "Clinical presentation of celiac disease in the pediatric population," Gastroenterology, vol. 128, no. 4, pp. S68-S73, 2005.

[2] R. J. Farrell and C. P. Kelly, "Celiac sprue," New England Journal of Medicine, vol. 346, no. 3, pp. 180-188, 2002.

[3] D. J. Smyth, V. Plagnol, N. M. Walker, et al., "Shared and distinct genetic variants in type 1 diabetes and celiac disease," New England Journal of Medicine, vol. 359, no. 26, pp. 27672777, 2008.

[4] J. M. Barker and E. Liu, "Celiac disease: pathophysiology, clinical manifestations, and associated autoimmune conditions," Advances in Pediatrics, vol. 55, no. 1, pp. 349-365, 2008.

[5] M. Westerholm-Ormio, O. Vaarala, P. Pihkala, J. Ilonen, and E. Savilahti, "Immunologic activity in the small intestinal mucosa of pediatric patients with type 1 diabetes," Diabetes, vol. 52, no. 9, pp. 2287-2295, 2003.

[6] O. Vaarala, M. A. Atkinson, and J. Neu, "The "perfect storm" for type 1 diabetes: the complex interplay between intestinal microbiota, gut permeability, and mucosal immunity," Diabetes, vol. 57, no. 10, pp. 2555-2562, 2008.

[7] A. Fasano, I. Berti, T. Gerarduzzi, et al., "Prevalence of Celiac disease in at-risk and not-at-risk groups in the United States: a large multicenter study," Archives of Internal Medicine, vol. 163, no. 3, pp. 286-292, 2003.

[8] M. Mäki, K. Mustalahti, J. Kokkonen, et al., "Prevalence of celiac disease among children in Finland," New England Journal of Medicine, vol. 348, no. 25, pp. 2517-2524, 2003.
[9] P. J. Bingley, A. J. K. Williams, A. J. Norcross, et al., "Undiagnosed coeliac disease at age seven: population based prospective birth cohort study," British Medical Journal, vol. 328, no. 7435, pp. 322-323, 2004.

[10] J. West, R. F. A. Logan, P. G. Hill, et al., "Seroprevalence, correlates, and characteristics of undetected coeliac disease in England," Gut, vol. 52, no. 7, pp. 960-965, 2003.

[11] A. Rubio-Tapia, R. A. Kyle, E. L. Kaplan, et al., "Increased prevalence and mortality in undiagnosed celiac disease," Gastroenterology, vol. 137, no. 1, pp. 88-93, 2009.

[12] K. S. Sher, R. C. Fraser, A. C. Wicks, and J. F. Mayberry, "High risk of coeliac disease in Punjabis. Epidemiological study in the South Asian and European populations of Leicestershire," Digestion, vol. 54, no. 3, pp. 178-182, 1993.

[13] K. Barada, A. Bitar, A. Mokadem, M. A. Brandt, J. G. Hashash, and P. Green, "Celiac disease in Middle Eastern and North African countries: a new burden?" World Journal Gastroenterology, vol. 16, no. 12, pp. 1449-1457, 2010.

[14] T. Saukkonen, E. Savilahti, H. Reijonen, et al., "Coeliac disease: frequent occurrence after clinical onset of insulindependent diabetes mellitus," Diabetic Medicine, vol. 13, no. 5, pp. 464-470, 1996.

[15] M. B. Roldan, R. Barrio, G. Roy, et al., "Diagnostic value of serological markers for celiac disease in diabetic children and adolescents," Journal of Pediatric Endocrinology and Metabolism, vol. 11, no. 6, pp. 751-756, 1998.

[16] J. Crone, B. Rami, W. D. Huber, G. Granditsch, and E. Schober, "Prevalence of celiac disease and follow-up of EMA in children and adolescents with type 1 diabetes mellitus," Journal of Pediatric Gastroenterology and Nutrition, vol. 37, no. 1, pp. 67-71, 2003.

[17] D. Hansen, B. Brock-Jacobsen, E. Lund, et al., "Clinical benefit of a gluten-free diet in type 1 diabetic children with screening-detected celiac disease: a population-based screening study with 2 years' follow-up," Diabetes Care, vol. 29, no. 11, pp. 2452-2456, 2006.

[18] C. Goh and K. Banerjee, "Prevalence of coeliac disease in children and adolescents with type 1 diabetes mellitus in a clinic based population,” Postgraduate Medical Journal, vol. 83, no. 976, pp. 132-136, 2007.

[19] K. Larsson, A. Carlsson, E. Cederwall, et al., "Annual screening detects celiac disease in children with type 1 diabetes," Pediatric Diabetes, vol. 9, no. 4, pp. 354-359, 2008.

[20] S. Salardi, U. Volta, S. Zucchini, et al., "Prevalence of celiac disease in children with type 1 diabetes mellitus increased in the mid-1990 s: an 18-year longitudinal study based on antiendomysial antibodies," Journal of Pediatric Gastroenterology and Nutrition, vol. 46, no. 5, pp. 612-614, 2008.

[21] K. Karavanaki, K. Kakleas, E. Paschali, et al., "Screening for associated autoimmunity in children and adolescents with type 1 diabetes mellitus (T1DM)," Hormone Research, vol. 71, no. 4, pp. 201-206, 2009.

[22] A. N. Aktay, P. C. Lee, V. Kumar, E. Parton, D. T. Wyatt, and S. L. Werlin, "The prevalence and clinical characteristics of celiac disease in juvenile diabetes in Wisconsin," Journal of Pediatric Gastroenterology and Nutrition, vol. 33, no. 4, pp. 462-465, 2001.

[23] P. M. Gillett, H. R. Gillett, D. M. Israel, et al., "High prevalence of celaic disease in patients with type 1 diabetes detected by antibodies to endomysium and tissue transglutaminase," Canadian Journal of Gastroenterology, vol. 15, no. 5, pp. 297-301, 2001. 
[24] M. L. Baptista, Y. K. L. Koda, R. Mitsunori, R. Nisihara, and S. O. Ioshii, "Prevalence of celiac disease in Brazilian children and adolescents with type 1 diabetes mellitus," Journal of Pediatric Gastroenterology and Nutrition, vol. 41, no. 5, pp. 621-624, 2005.

[25] G. Boudraa, W. Hachelaf, M. Benbouabdellah, M. Belkadi, F. Z. Benmansour, and M. Touhami, "Prevalence of coeliac disease in diabetic children and their first- degree relatives in west Algeria: screening with serological markers," Acta Paediatrica, vol. 412, pp. 58-60, 1996.

[26] A. Ashabani, U. Abushofa, S. Abusrewill, M. Abdelazez, L. Tučková, and H. Tlaskalová-Hogenova, "The prevalence of coeliac disease in Libyan children with type 1 diabetes mellitus," Diabetes/Metabolism Research and Reviews, vol. 19, no. 1, pp. 69-75, 2003.

[27] N. Salah, F. A. El Hamid, S. Abdelghaffar, and M. El Sayem, "Prevalence and type of anaemia in young Egyptian patients with type 1 diabetes mellitus," Eastern Mediterranean Health Journal, vol. 11, no. 5-6, pp. 959-967, 2005.

[28] A. Mankaï, H. Ben Hamouda, F. Amri, et al., "Screening by anti-endomysium antibodies for celiac disease in Tunisian children with type 1 diabetes mellitus," Gastroenterologie Clinique et Biologique, vol. 31, no. 5, pp. 462-466, 2007.

[29] C. M. Smith, C. F. Clarke, L. E. Porteous, H. Elsori, and D. J. Cameron, "Prevalence of coeliac disease and longitudinal follow-up of antigliadin antibody status in children and adolescents with type 1 diabetes mellitus," Pediatric Diabetes, vol. 1, no. 4, pp. 199-203, 2000.

[30] A. A. Al-Ashwal, S. M. Shabib, N. A. Sakati, and N. A. Attia, "Prevalence and characteristics of celiac disease in type I diabetes mellitus in Saudi Arabia," Saudi Medical Journal, vol. 24, no. 10, pp. 1113-1115, 2003.

[31] G.-H. Fallahi, J. H. Ahmadian, A. Rabbani, A. Yousefnezhad, and N. Rezaei, "Screening for celiac disease in diabetic children from Iran," Indian Pediatrics, vol. 47, no. 3, pp. 268270, 2010.

[32] D. Schuppan and E. G. Hahn, "Celiac disease and its link to type 1 diabetes mellitus," Journal of Pediatric Endocrinology and Metabolism, vol. 14, no. 1, pp. 597-605, 2001.

[33] K. A. Fraser-Reynolds, J. D. Butzner, D. K. Stephure, R. A. Trussell, and R. B. Scott, "Use of immunoglobulin Aantiendomysial antibody to screen for celiac disease in North American children with type 1 diabetes," Diabetes Care, vol. 21, no. 11, pp. 1985-1989, 1998.

[34] F. H. Mahmud, J. A. Murray, Y. C. Kudva, et al., "Celiac disease in type 1 diabetes melittus in a North American community: prevalence, serologic screening, and clinical features," Mayo Clinic Proceedings, vol. 80, no. 11, pp. 14291434, 2005.

[35] E. E. Fröhlich-Reiterer, S. Hofer, S. Kaspers, et al., "Screening frequency for celiac disease and autoimmune thyroiditis in children and adolescents with type 1 diabetes mellitusdata from a German/Austrian multicentre survey," Pediatric Diabetes, vol. 9, no. 6, pp. 546-553, 2008.

[36] G. Telega, T. R. Bennet, and S. Werlin, "Emerging new clinical patterns in the presentation of celiac disease," Archives of Pediatrics and Adolescent Medicine, vol. 162, no. 2, pp. 164168, 2008.

[37] K. E. McGowan, D. A. Castiglione, and J. D. Butzner, “The changing face of childhood celiac disease in North America: impact of serological testing," Pediatrics, vol. 124, no. 6, pp. 1572-1578, 2009.
[38] B. Rami, Z. Sumnik, E. Schober, et al., "Screening detected celiac disease in children with type 1 diabetes mellitus: effect on the clinical course (a case control study)," Journal of Pediatric Gastroenterology and Nutrition, vol. 41, no. 3, pp. 317-321, 2005.

[39] E. J. Hoffenberg, L. M. Emery, K. J. Barriga, et al., "Clinical features of children with screening-identified evidence of celiac disease," Pediatrics, vol. 113, no. 5, pp. 1254-1259, 2004.

[40] R. F. R. Steens, C. G. D. S. Csizmadia, E. K. George, M. K. Ninaber, R. A. Hira Sing, and M. L. Mearin, "A national prospective study on childhood celiac disease in the Netherlands 1993-2000: an increasing recognition and a changing clinical picture," Journal of Pediatrics, vol. 147, no. 2, pp. 239-243, 2005.

[41] M. Hummel, A.-G. Ziegler, and E. Bonifacio, "Type 1 diabetes mellitus, celiac disease and their associationlessons from antibodies," Journal of Pediatric Endocrinology and Metabolism, vol. 14, no. 1, pp. 607-610, 2001.

[42] C. P. Kelly, C. F. Feighery, R. B. Gallagher, and D. G. Weir, "Diagnosis and treatment of gluten-sensitive enteropathy," Advances in Internal Medicine, vol. 35, pp. 341-363, 1990.

[43] G. R. Corazza, M. Frisoni, E. A. Treggiari, et al., "Subclinical celiac sprue: increasing occurrence and clues to its diagnosis," Journal of Clinical Gastroenterology, vol. 16, no. 1, pp. 16-21, 1993.

[44] S. A. McMillan, R. P. G. Watson, E. E. McCrum, and A. E. Evans, "Factors associated with serum antibodies to reticulin, endomysium, and gliadin in an adult population," Gut, vol. 39, no. 1, pp. 43-47, 1996.

[45] I. D. Hill, "What are the sensitivity and specificity of serologic tests for celiac disease? Do sensitivity and specificity vary in different populations?" Gastroenterology, vol. 128, no. 4, supplement 1, pp. S25-S32, 2005.

[46] "AGA Institute medical position statement on the diagnosis and management of celiac disease," Gastroenterology, vol. 131, no. 6, pp. 1977-1980, 2006.

[47] V. Kumar, M. Jarzabek-Chorzelska, J. Sulej, K. Karnewska, T. Farrell, and S. Jablonska, "Celiac disease and immunoglobulin a deficiency: how effective are the serological methods of diagnosis?" Clinical and Diagnostic Laboratory Immunology, vol. 9, no. 6, pp. 1295-1300, 2002.

[48] F. Cataldo, V. Marino, G. Bottaro, P. Greco, and A. Ventura, "Celiac disease and selective immunoglobulin a deficiency," Journal of Pediatrics, vol. 131, no. 2, pp. 306-308, 1997.

[49] M. A. Heneghan, F. M. Stevens, E. M. Cryan, R. H. Warner, and C. F. McCarthy, "Celiac sprue and immunodeficiency states: a 25-year review," Journal of Clinical Gastroenterology, vol. 25, no. 2, pp. 421-425, 1997.

[50] F. Cataldo, V. Marino, A. Ventura, G. Bottaro, and G. R. Corazza, "Prevalence and clinical features of selective immunoglobulin A deficiency in coeliac disease: an Italian multicentre study. Italian Society of Paediatric Gastroenterology and Hepatology (SIGEP) and "Club del Tenue"," Gut, vol. 42, no. 3, pp. 362-365, 1998.

[51] M. Ballow, "Primary immunodeficiency disorders: antibody deficiency," Journal of Allergy and Clinical Immunology, vol. 109, no. 4, pp. 581-591, 2002.

[52] A. H. A. Latiff and M. A. Kerr, "The clinical significance of immunoglobulin A deficiency," Annals of Clinical Biochemistry, vol. 44, no. 2, pp. 131-139, 2007. 
[53] D. C. Weir, J. N. Glickman, T. Roiff, C. Valim, and A. M. Leichtner, "Variability of histopathological changes in childhood celiac disease," American Journal of Gastroenterology, vol. 105, no. 1, pp. 207-212, 2010.

[54] W. P. Pais, D. R. Duerksen, N. M. Pettigrew, and C. N. Bernstein, "How many duodenal biopsy specimens are required to make a diagnosis of celiac disease?" Gastrointestinal Endoscopy, vol. 67, no. 7, pp. 1082-1087, 2008.

[55] O. Kordonouri, A. M. Maguire, M. Knip, et al., "ISPAD Clinical Practice Consensus Guidelines 2006-2007. Other complications and associated conditions," Pediatric Diabetes, vol. 8, no. 3, pp. 171-176, 2007.

[56] I. D. Hill, M. H. Dirks, G. S. Liptak, et al., "Guideline for the diagnosis and treatment of celiac disease in children: recommendations of the North American Society for Pediatric Gastroenterology, Hepatology and Nutrition," Journal of Pediatric Gastroenterology and Nutrition, vol. 40, no. 1, pp. 1-19, 2005.

[57] "Canadian Diabetes Association 2008 Clinical Practice Guidelines for the Prevention and Management of Diabetes in Canada," Canadian Journal of Diabetes, vol. 32, supplement 1, pp. 22-35, 2008.

[58] "Standards of medical care in diabetes-2009," Diabetes Care, vol. 32, supplement 1, pp. S13-S61, 2009.

[59] "NIH consensus development conference on celiac disease," NIH Consensus and State-of-the-Science Statements, vol. 21, no. 1, pp. 1-23, 2004.

[60] M. Rashid, D. Butzner, V. Burrows, et al., "Consumption of pure oats by individuals with celiac disease: a position statement by the Canadian Celiac Association," Canadian Journal of Gastroenterology, vol. 21, no. 10, pp. 649-651, 2007.

[61] E. Fabiani, C. Catassi, A. Villari, et al., "Dietary compliance in screening-detected coeliac disease adolescents," Acta Paediatrica, vol. 412, pp. 65-67, 1996.

[62] K. D. Fine, R. L. Meyer, and E. L. Lee, "The prevalence and causes of chronic diarrhea in patients with celiac sprue treated with a gluten-free diet," Gastroenterology, vol. 112, no. 6, pp. 1830-1838, 1997.

[63] A. S. Abdulkarim, L. J. Burgart, J. See, and J. A. Murray, "Etiology of nonresponsive celiac disease: results of a systematic approach," American Journal of Gastroenterology, vol. 97, no. 8, pp. 2016-2021, 2002.

[64] C. Ciacci, M. Cirillo, R. Cavallaro, and G. Mazzacca, "Longterm follow-up of celiac adults on gluten-free diet: prevalence and correlates of intestinal damage," Digestion, vol. 66, no. 3, pp. 178-185, 2002.

[65] T. Matysiak-Budnik, G. Malamut, N. P.-M. De Serre, et al., "Long-term follow-up of 61 coeliac patients diagnosed in childhood: evolution toward latency is possible on a normal diet," Gut, vol. 56, no. 10, pp. 1379-1386, 2007.

[66] M. Lang-Muritano, L. Molinari, C. Dommann-Scherrer, G. Schueler, and E. J. Schoenle, "Incidence of enteropathyassociated T-cell lymphoma in celiac disease: implications for children and adolescents with type 1 diabetes," Pediatric Diabetes, vol. 3, no. 1, pp. 42-45, 2002.

[67] E. Westman, G. R. Ambler, M. Royle, J. Peat, and A. Chan, "Children with coeliac disease and insulin dependent diabetes mellitus - growth, diabetes control and dietary intake," Journal of Pediatric Endocrinology and Metabolism, vol. 12, no. 3, pp. 433-442, 1999.

[68] P. Mariani, M. G. Viti, M. Montuori, et al., "The glutenfree diet: a nutritional risk factor for adolescents with celiac disease?" Journal of Pediatric Gastroenterology and Nutrition, vol. 27, no. 5, pp. 519-523, 1998.

[69] L. Greco, M. Mayer, G. Ciccarelli, R. Troncone, and S. Auricchio, "Compliance to a gluten-free diet in adolescents, or "what do 300 coeliac adolescents eat every day?"," Italian Journal of Gastroenterology and Hepatology, vol. 29, no. 4, pp. 305-311, 1997.

[70] E. J. Van Koppen, J. J. Schweizer, C. G. D. S. Csizmadia, et al., "Long-term health and quality-of-life consequences of mass screening for childhood celiac disease: a 10-year follow-up study," Pediatrics, vol. 123, no. 4, pp. e582-e588, 2009.

[71] O. I. Saadah, M. Zacharin, A. O'Callaghan, M. R. Oliver, and A. G. Catto-Smith, "Effect of gluten-free diet and adherence on growth and diabetic control in diabetics with coeliac disease," Archives of Disease in Childhood, vol. 89, no. 9, pp. 871-876, 2004.

[72] G. Wagner, G. Berger, U. Sinnreich, et al., "Quality of life in adolescents with treated coeliac disease: influence of compliance and age at diagnosis," Journal of Pediatric Gastroenterology and Nutrition, vol. 47, no. 5, pp. 555-561, 2008.

[73] E. G. D. Hopman, S. Le Cessie, B. M. E. von Blomberg, and M. L. Mearin, "Nutritional management of the gluten-free diet in young people with celiac disease in The Netherlands," Journal of Pediatric Gastroenterology and Nutrition, vol. 43, no. 1, pp. 102-108, 2006.

[74] O. Jadresin, Z. Misak, K. Sanja, Z. Sonicki, and V. Zizić, "Compliance with gluten-free diet in children with coeliac disease," Journal of Pediatric Gastroenterology and Nutrition, vol. 47, no. 3, pp. 344-348, 2008.

[75] O. Anson, Z. Weizman, and N. Zeevi, "Celiac disease: parental knowledge and attitudes of dietary compliance," Pediatrics, vol. 85, no. 1, pp. 98-103, 1990.

[76] E. Fabiani, L. M. Taccari, I.-M. Rätsch, S. Di Giuseppe, G. V. Coppa, and C. Catassi, "Compliance with gluten-free diet in adolescents with screening-detected celiac disease: a 5-year follow-up study," Journal of Pediatrics, vol. 136, no. 6, pp. 841-843, 2000.

[77] L. Högberg, E. Grodzinsky, and L. Stenhammar, "Better dietary compliance in patients with coeliac disease diagnosed in early childhood," Scandinavian Journal of Gastroenterology, vol. 38, no. 7, pp. 751-754, 2003.

[78] D. A. Leffler, J. B. Edwards George, M. Dennis, E. F. Cook, D. Schuppan, and C. P. Kelly, "A prospective comparative study of five measures of gluten-free diet adherence in adults with coeliac disease," Alimentary Pharmacology and Therapeutics, vol. 26, no. 9, pp. 1227-1235, 2007.

[79] D. A. Leffler, M. Dennis, J. B. Edwards George, et al., "A simple validated gluten-free diet adherence survey for adults with celiac disease," Clinical Gastroenterology and Hepatology, vol. 7, no. 5, pp. 530-536, 2009.

[80] F. Biagi, A. Andrealli, P. I. Bianchi, A. Marchese, C. Klersy, and G. R. Corazza, "A gluten-free diet score to evaluate dietary compliance in patients with coeliac disease," British Journal of Nutrition, vol. 102, no. 6, pp. 882-887, 2009.

[81] I. Sanchez-Albisua, J. Wolf, A. Neu, H. Geiger, I. Wäscher, and M. Stern, "Coeliac disease in children with type 1 diabetes mellitus: the effect of the gluten-free diet," Diabetic Medicine, vol. 22, no. 8, pp. 1079-1082, 2005.

[82] S. Sun, R. Puttha, S. Ghezaiel, M. Skae, C. Cooper, and R. Amin, "The effect of biopsy-positive silent coeliac disease and treatment with a gluten-free diet on growth and glycaemic 
control in children with type 1 diabetes," Diabetic Medicine, vol. 26, no. 12, pp. 1250-1254, 2009.

[83] C. Olsson, A. Hörnell, A. Ivarsson, and Y. M. Sydner, "The everyday life of adolescent coeliacs: issues of importance for compliance with the gluten-free diet," Journal of Human Nutrition and Dietetics, vol. 21, no. 4, pp. 359-367, 2008.

[84] A. R. Lee, D. L. Ng, J. Zivin, and P. H. R. Green, "Economic burden of a gluten-free diet," Journal of Human Nutrition and Dietetics, vol. 20, no. 5, pp. 423-430, 2007.

[85] L. Stevens and M. Rashid, "Gluten-free and regular foods: a cost comparison," Canadian Journal of Dietetic Practice and Research, vol. 69, no. 3, pp. 147-150, 2008.

[86] C. Kupper, "Dietary guidelines and implementation for celiac disease," Gastroenterology, vol. 128, no. 4, supplement 1, pp. S121-S127, 2005.

[87] Canadian Celiac Association, "Gluten-free Labelling Canada," January 2009.

[88] T. Saukkonen, J. Ilonen, H. K. Åkerblom, et al., "Prevalence of coeliac disease in siblings of patients with type I diabetes is related to the prevalence of DQB1*02 allele," Diabetologia, vol. 44, no. 8, pp. 1051-1053, 2001.

[89] M. Graue, T. Wentzel-Larsen, B. R. Hanestad, B. Båtsvik, and O. Søvik, "Measuring self-reported, health-related, quality of life in adolescents with type 1 diabetes using both generic and disease-specific instruments," Acta Paediatrica, vol. 92, no. 10, pp. 1190-1196, 2003.

[90] M. Grey, E. A. Boland, C. Yu, S. Sullivan-Bolyai, and W. V. Tamborlane, "Personal and family factors associated with quality of life in adolescents with diabetes," Diabetes Care, vol. 21, no. 6, pp. 909-914, 1998.

[91] M. Pompili, D. Lester, M. Innamorati, et al., "Quality of life and suicide risk in patients with diabetes mellitus," Psychosomatics, vol. 50, no. 1, pp. 16-23, 2009.

[92] R. R. Rubin and M. Peyrot, "Quality of life and diabetes," Diabetes/Metabolism Research and Reviews, vol. 15, no. 3, pp. 205-218, 1999.

[93] F. Nachman, E. Mauriño, H. Vázquez, et al., "Quality of life in celiac disease patients. Prospective analysis on the importance of clinical severity at diagnosis and the impact of treatment," Digestive and Liver Disease, vol. 41, no. 1, pp. 15-25, 2009.

[94] A. Galatzer, E. Green, R. Ofan, et al., "Psychological impact of islet cell antibody screening," Journal of Pediatric Endocrinology and Metabolism, vol. 14, no. 1, pp. 675-679, 2001.

[95] J. Gass, M. T. Bethune, M. Siegel, A. Spencer, and C. Khosla, "Combination enzyme therapy for gastric digestion of dietary gluten in patients with celiac sprue," Gastroenterology, vol. 133, no. 2, pp. 472-480, 2007.

[96] B. M. Paterson, K. M. Lammers, M. C. Arrieta, A. Fasano, and J. B. Meddings, "The safety, tolerance, pharmacokinetic and pharmacodynamic effects of single doses of AT-1001 in coeliac disease subjects: a proof of concept study," Alimentary Pharmacology and Therapeutics, vol. 26, no. 5, pp. 757-766, 2007.

[97] J. Xia, E. Bergseng, B. Fleckenstein, et al., "Cyclic and dimeric gluten peptide analogues inhibiting DQ2-mediated antigen presentation in celiac disease," Bioorganic and Medicinal Chemistry, vol. 15, no. 20, pp. 6565-6573, 2007.

[98] M. Freemark and L. L. Levitsky, "Screening for celiac disease in children with type 1 diabetes: two views of the controversy," Diabetes Care, vol. 26, no. 6, pp. 1932-1939, 2003.
[99] N. Binkley, J. P. Bilezikian, D. L. Kendler, E. S. Leib, E. M. Lewiecki, and S. M. Petak, "Summary of the International Society for Clinical Densitometry 2005 Position Development Conference," Journal of Bone and Mineral Research, vol. 22, no. 5, pp. 643-645, 2007.

[100] L. A. Soyka, W. P. Fairfield, and A. Klibanski, "Hormonal determinants and disorders of peak bone mass in children," Journal of Clinical Endocrinology and Metabolism, vol. 85, no. 11, pp. 3951-3963, 2000.

[101] S. Mora, G. Weber, G. Barera, et al., "Effect of gluten-free diet on bone mineral content in growing patients with celiac disease," American Journal of Clinical Nutrition, vol. 57, no. 2, pp. 224-228, 1993.

[102] A. G. Kalayci, A. Kansu, N. Girgin, O. Kucuk, and G. Aras, "Bone mineral density and importance of a gluten-free diet in patients with celiac disease in childhood," Pediatrics, vol. 108, no. 5, p. E89, 2001.

[103] G. Barera, S. Beccio, M. C. Proverbio, and S. Mora, "Longitudinal changes in bone metabolism and bone mineral content in children with celiac disease during consumption of a gluten-free diet," American Journal of Clinical Nutrition, vol. 79, no. 1, pp. 148-154, 2004.

[104] C. Tau, C. Mautalen, S. De Rosa, A. Roca, and X. Valenzuela, "Bone mineral density in children with celiac disease. Effect of a Gluten-free diet," European Journal of Clinical Nutrition, vol. 60, no. 3, pp. 358-363, 2006.

[105] C. Hartman, B. Hino, A. Lerner, et al., "Bone quantitative ultrasound and bone mineral density in children with celiac disease," Journal of Pediatric Gastroenterology and Nutrition, vol. 39, no. 5, pp. 504-510, 2004.

[106] J. Turner, G. Pellerin, and D. Mager, "Prevalence of metabolic bone disease in children with celiac disease is independent of symptoms at diagnosis," Journal of Pediatric Gastroenterology and Nutrition, vol. 49, no. 5, pp. 589-593, 2009.

[107] Y. Rakover, H. Hager, E. Nussinson, and R. Luboshitzky, "Celiac disease as a cause of transient hypocalcemia and hypovitaminosis D in a 13 year-old girl," Journal of Pediatric Endocrinology, vol. 7, no. 1, pp. 53-55, 1994.

[108] F. Rea, C. Polito, A. Marotta, et al., "Restoration of body composition in celiac children after one year of gluten-free diet," Journal of Pediatric Gastroenterology and Nutrition, vol. 23, no. 4, pp. 408-412, 1996.

[109] A. Challa, A. Moulas, V. Cholevas, E. Karastergiou, D. Lapatsanis, and E. Tsianos, "Vitamin D metabolites in patients with coeliac disease," European Journal of Pediatrics, vol. 157, no. 3, pp. 262-263, 1998.

[110] C. Sategna-Guidetti, S. B. Grosso, S. Grosso, et al., "The effects of 1-year gluten withdrawal on bone mass, bone metabolism and nutritional status in newly-diagnosed adult coeliac disease patients," Alimentary Pharmacology and Therapeutics, vol. 14, no. 1, pp. 35-43, 2000.

[111] G. R. Corazza, A. Di Sario, L. Cecchetti, et al., "Bone mass and metabolism in patients with celiac disease," Gastroenterology, vol. 109, no. 1, pp. 122-128, 1995.

[112] A. P. Keaveny, R. Freaney, M. J. McKenna, J. Masterson, and D. P. O'Donoghue, "Bone remodeling indices and secondary hyperparathyroidism in celiac disease," American Journal of Gastroenterology, vol. 91, no. 6, pp. 1226-1231, 1996.

[113] E. C. Weir, M. C. Horowitz, R. Baron, M. Centrella, B. M. Kacinski, and K. L. Insogna, "Macrophage colonystimulating factor release and receptor expression in bone cells," Journal of Bone and Mineral Research, vol. 8, no. 12, pp. 1507-1518, 1993. 
[114] S. L. Abboud, K. Woodruff, C. Liu, V. Shen, and N. Ghosh-Choudhury, "Rescue of the osteopetrotic defect in op/op mice by osteoblast-specific targeting of soluble colony stimulating factor-1," Endocrinology, vol. 143, no. 5, pp. 1942-1949, 2002.

[115] S.-K. Lee and J. Lorenzo, "Cytokines regulating osteoclast formation and function," Current Opinion in Rheumatology, vol. 18, no. 4, pp. 411-418, 2006.

[116] R. Felix, H. Fleisch, and P. R. Elford, "Bone-resorbing cytokines enhance release of macrophage colony-stimulating activity of the osteoblastic cell MC3T3-E1," Calcified Tissue International, vol. 44, no. 5, pp. 356-360, 1989.

[117] F. Arai, T. Miyamoto, O. Ohneda, et al., "Commitment and differentiation of osteoclast precursor cells by the sequential expression of c-Fms and receptor activator of nuclear factor $\kappa \mathrm{B}$ (RANK) receptors," Journal of Experimental Medicine, vol. 190, no. 12, pp. 1741-1754, 1999.

[118] K. Fuller, B. Wong, S. Fox, Y. Choi, and T. J. Chambers, "TRANCE is necessary and sufficient for osteoblast-mediated activation of bone resorption in osteoclasts," Journal of Experimental Medicine, vol. 188, no. 5, pp. 997-1001, 1998.

[119] D. L. Lacey, E. Timms, H.-L. Tan, et al., "Osteoprotegerin ligand is a cytokine that regulates osteoclast differentiation and activation," Cell, vol. 93, no. 2, pp. 165-176, 1998.

[120] A. Taranta, D. Fortunati, M. Longo, et al., "Imbalance of osteoclastogenesis-regulating factors in patients with celiac disease," Journal of Bone and Mineral Research, vol. 19, no. 7, pp. 1112-1121, 2004.

[121] C. E. Fiore, P. Pennisi, G. Ferro, et al., "Altered osteoprotegerin/RANKL ratio and low bone mineral density in celiac patients on long-term treatment with gluten-free diet," Hormone and Metabolic Research, vol. 38, no. 6, pp. 417-422, 2006.

[122] M. M. Campos Pastor, P. J. López-Ibarra, F. Escobar-Jiménez, M. D. Serrano Pardo, and A. García-Cervigón, "Intensive insulin therapy and bone mineral density in type 1 diabetes mellitus: a prospective study," Osteoporosis International, vol. 11, no. 5, pp. 455-459, 2000.

[123] P. Gunczler, R. Lanes, V. Paz-Martinez, et al., "Decreased lumbar spine bone mass and low bone turnover in children and adolescents with insulin dependent diabetes mellitus followed longitudinally," Journal of Pediatric Endocrinology and Metabolism, vol. 11, no. 3, pp. 413-419, 1998.

[124] P. Gunczler, R. Lanes, M. Paoli, R. Martinis, O. Villaroel, and J. R. Weisinger, "Decreased bone mineral density and bone formation markers-shortly after diagnosis of clinical type 1 diabetes mellitus," Journal of Pediatric Endocrinology and Metabolism, vol. 14, no. 5, pp. 525-528, 2001.

[125] J. Heap, M. A. Murray, S. C. Miller, T. Jalili, and L. J. Moyer-Mileur, "Alterations in bone characteristics associated with glycemic control in adolescents with type 1 diabetes mellitus," Journal of Pediatrics, vol. 144, no. 1, pp. 56-62, 2004.

[126] G. Leidig-Bruckner and R. Ziegler, "Diabetes mellitus a risk for osteoporosis?" Experimental and Clinical Endocrinology and Diabetes, vol. 109, no. 2, pp. S493-S514, 2001.

[127] S. Mora, G. Barera, S. Beccio, et al., "Bone density and bone metabolism are normal after long-term gluten-free diet in young celiac patients," American Journal of Gastroenterology, vol. 94, no. 2, pp. 398-403, 1999.

[128] M. S. Scotta, S. Salvatore, A. Salvatoni, et al., "Bone mineralization and body composition in young patients with celiac disease," American Journal of Gastroenterology, vol. 92, no. 8, pp. 1331-1334, 1997.

[129] S. Mora, G. Barera, S. Beccio, et al., "A prospective, longitudinal study of the long-term effect of treatment on bone density in children with celiac disease," Journal of Pediatrics, vol. 139, no. 4, pp. 516-521, 2001.

[130] E. Artz, J. Warren-Ulanch, D. Becker, S. Greenspan, and M. Freemark, "Seropositivity to celiac antigens in asymptomatic children with type 1 diabetes mellitus: association with weight, height, and bone mineralization," Pediatric Diabetes, vol. 9, no. 4, pp. 277-284, 2008.

[131] J. H. Simmons, G. J. Klingensmith, K. McFann, et al., "Impact of celiac autoimmunity on children with type 1 diabetes," Journal of Pediatrics, vol. 150, no. 5, pp. 461-466, 2007.

[132] D. R. Diniz-Santos, F. Brandão, L. Adan, A. Moreira, E. J. Vicente, and L. R. Silva, "Bone mineralization in young patients with type 1 diabetes mellitus and screeningidentified evidence of celiac disease," Digestive Diseases and Sciences, vol. 53, no. 5, pp. 1240-1245, 2008.

[133] Y. Gao, S. Y. Kristinsson, L. R. Goldin, M. Björkholm, N. E. Caporaso, and O. Landgren, "Increased risk for nonHodgkin lymphoma in individuals with celiac disease and a potential familial association," Gastroenterology, vol. 136, no. 1, pp. 91-98, 2009.

[134] L. A. Anderson, S. Gadalla, L. M. Morton, et al., "Populationbased study of autoimmune conditions and the risk of specific lymphoid malignancies," International Journal of Cancer, vol. 125, no. 2, pp. 398-405, 2009.

[135] G. K. T. Holmes, P. Prior, M. R. Lane, D. Pope, and R. N. Allan, "Malignancy in coeliac disease-effect of a gluten free diet," Gut, vol. 30, no. 3, pp. 333-338, 1989.

[136] M. J. G. Farthing, C. R. Edwards, L. H. Rees, and A. M. Dawson, "Male gonadal function in coeliac disease: 1 . Sexual dysfunction, infertility, and semen quality," Gut, vol. 23, no. 7, pp. 608-614, 1982.

[137] N. Molteni, M. T. Bardella, and P. A. Bianchi, "Obstetric and gynecological problems in women with untreated celiac sprue," Journal of Clinical Gastroenterology, vol. 12, no. 1, pp. 37-39, 1990.

[138] E. Smecuol, E. Mauriño, H. Vazquez, et al., "Gynaecological and obstetric disorders in coeliac disease: frequent clinical onset during pregnancy or the puerperium," European Journal of Gastroenterology and Hepatology, vol. 8, no. 1, pp. 63-67, 1996.

[139] C. Mautalen, D. Gonzalez, R. Mazure, et al., "Effect of treatment on bone mass, mineral metabolism, and body composition in untreated celiac disease patients," American Journal of Gastroenterology, vol. 92, no. 2, pp. 313-318, 1997.

[140] B. Nørgård, K. Fonager, H. T. Sørensen, and J. Olsen, "Birth outcomes of women with celiac disease: a nationwide historical cohort study," American Journal of Gastroenterology, vol. 94, no. 9, pp. 2435-2440, 1999.

[141] J. F. Ludvigsson and J. Ludvigsson, "Coeliac disease in the father affects the newborn," Gut, vol. 49, no. 2, pp. 169-175, 2001.

[142] C. Ciacci, M. Cirillo, G. Auriemma, G. Di Dato, F. Sabbatini, and G. Mazzacca, "Celiac disease and pregnancy outcome," American Journal of Gastroenterology, vol. 91, no. 4, pp. 718722, 1996.

[143] A. S. Khashan, T. B. Henriksen, P. B. Mortensen, et al., "The impact of maternal celiac disease on birthweight and preterm birth: a Danish population-based cohort study," Human Reproduction, vol. 25, no. 2, pp. 528-534, 2010. 
[144] L. J. Tata, T. R. Card, R. F. A. Logan, R. B. Hubbard, C. J. P. Smith, and J. West, "Fertility and pregnancy-related events in women with celiac disease: a population-based cohort study," Gastroenterology, vol. 128, no. 4, pp. 849-855, 2005.

[145] C. Ciacci, P. Iovino, D. Amoruso, et al., "Grown-up coeliac children: the effects of only a few years on a gluten-free diet in childhood," Alimentary Pharmacology and Therapeutics, vol. 21, no. 4, pp. 421-429, 2005.

[146] M.-H. Metzger, M. Heier, M. Mäki, et al., "Mortality excess in individuals with elevated IgA anti-transglutaminase antibodies: the KORA/MONICA Augsburg cohort study 1989-1998," European Journal of Epidemiology, vol. 21, no. 5, pp. 359-365, 2006.

[147] J. F. Ludvigsson, S. M. Montgomery, A. Ekbom, L. Brandt, and F. Granath, "Small-intestinal histopathology and mortality risk in celiac disease," Journal of the American Medical Association, vol. 302, no. 11, pp. 1171-1178, 2009. 